\title{
Effects of Cytokinin and Auxin on Plant Development and Vascular Tissues in Lens culinaris
}

\author{
Haydar KÜPLEMEZ1,2*, Mehmet Uğur YILDIRIM³ \\ ${ }^{1}$ Department of Field Crops, Faculty of Agriculture and Natural Sciences, Recep Tayyip Erdogan University, 53300 Rize, Turkey \\ ${ }^{2}$ Department of Agricultural Sciences, Institute of Natural and Applied Sciences, Uşak University, 64000 Uşak, Turkey \\ ${ }^{3}$ Department of Field Crops, Faculty of Agriculture and Natural Sciences, Usak University, 64000 Usak, Turkey \\ ORCID ID: Haydar KÜPLEMEZ: https:/ / orcid.org/0000-0003-4094-1318; Mehmet Uğur YILDIRIM: https:/ / orcid.org/0000-0002-7419-0682
}

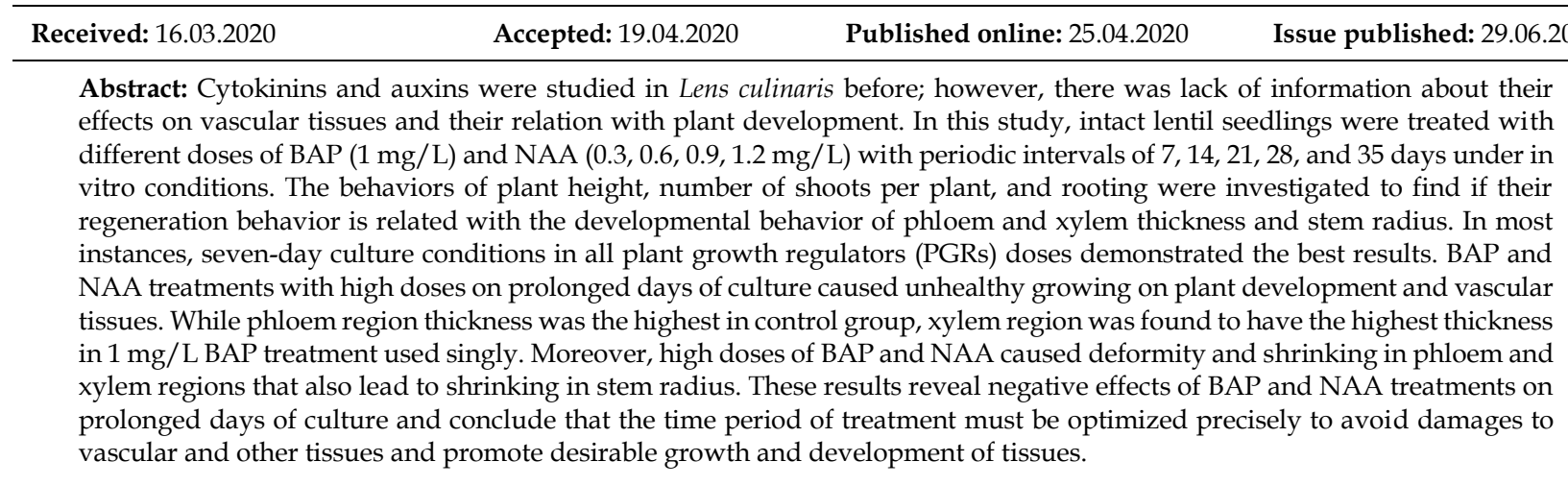

Keywords: Tissue culture, Benzylaminopurine (BAP), Naphthaleneacetic acid (NAA), phloem, xylem.

\section{Lens culinaris'te Sitokinin ve Oksinin Bitki Gelişimi ve Vasküler Dokular Üzerine Etkileri}

Öz: Sitokininler ve oksinlerin Lens culinaris'te daha önce çalışılmasına rağmen bunların vasküler dokular ve bitki gelişimi üzerine olan etkileri hakkında bilgi bulunmamaktadır. Bu çalışmada, bütün mercimek bitkicikleri çeşitli BAP $(1 \mathrm{mg} / \mathrm{L})$ ve NAA dozlarında $(0.3,0.6,0.9,1.2 \mathrm{mg} / \mathrm{L})$ periyodik $7,14,21,28$ ve 35 gün aralıklarında in vitro koşullarda kültüre alınmıştır. Bitki boyu, her bitkideki sürgün sayısı ve köklenmenin rejenerasyon davranışlarının; floem ve ksilem bölgesinin kalınlığının gelişimsel davranışı ve gövde çapının kalınlığı ile bir ilişkisinin olup olmadığı araştırılmıştır. Çoğu durumda, 7 günlük kültür koşulları tüm bitki büyüme düzenleyicileri dozlarında en iyi sonuçları göstermiştir. Yüksek dozdaki BAP ve NAA uygulamaları, uzatılan kültür günü sürelerinde bitki gelişimi ve vasküler dokular üzerinde sağlıksız gelişime neden olmuştur. Floem bölgesinin kalınlığı kontrol grubunda en yüksek olurken, ksilem bölgesinin yalnızca $1 \mathrm{mg} / \mathrm{L}$ BAP uygulamasında en yüksek kalınlığa sahip olduğu bulunmuştur. Ayrıca, yüksek BAP ve NAA dozları floem ve ksilem bölgesinde deformasyona ve daralmaya neden olmuştur ve gövde çapında daralmaya yol açmışır. Bu sonuçlar, uzayan kültür günü sürelerindeki bitki büyüme düzenleyicileri uygulamalarının olumsuz etkilerini ortaya çıkarmaktadır. Vasküler dokular ve diğer dokulardaki hasarı azaltmak, dokulardaki istenen büyüme ve gelişmeyi elde etmek için gün periyodunun tam olarak optimize edilmesi gerektiği sonucuna varılmaktadır.

Anahtar kelimeler: Doku kültürü, Benzilaminopürin (BAP), Naftalen asetik asit (NAA), floem, ksilem.

\section{Introduction}

The lentil (Lens culinaris Medik. subsp. culinaris) is widely used in human nutrition due to its protein-rich seeds (Bhatty, 1988). It is suspected that several factors are responsible for reduced yields, including vulnerability to pests and diseases, massive drop in flowers, and postharvest losses (Solh, 1984). In order to increase the lentil production and the yield per unit area, it is necessary to develop and spread new varieties. There is substantial potential of lentil under such circumstances to accept biotechnological methods for improving lentils such as tissue culture. Nevertheless, the lentil improvement by biotechnology approaches has appeared to be limited and difficult to regenerate due to its recalcitrant disposition (Khanam, Sarker, Hoque, \& Haque, 1995; Polanco \& Ruiz, 1997; Khawar \& Ozcan 2002; Sarker et al., 2003; Khawar, Sancak, Uranbey, \& Ozcan, 2004; Sevimay, Khawar, \&
Yuzbasioglu, 2005).

A number of previous studies have been carried out to establish effective in vitro tissue culture regeneration systems and to work out the possibility of adapting biotechnology to programs for lentil development. Treatments of cytokinins have an important role largely on inducing shoot regeneration while auxins mainly have an effect upon rooting induction (Saxena \& King 1987; Polanco, Pelaez, \& Ruiz, 1988; Sarker et al., 2003; Khawar, Sancak, Uranbey, \& Ozcan, 2004; Chhabra, Chaudhary, Varma, Sainger, \& Jaiwal, 2008; Ozdemir, Turker, \& Khawar, 2015). Cytokinins, auxins, and cytokinin-auxin correlations are generally regarded as the most essential factor to control growth and initiate regeneration in plant tissue and organ cultures (Evans, Sharp, \& Flick, 1981). Among the plant development and growth, cytokinin and auxin perform quite vital roles such as regulating several 
developmental processes as well as the formation and maintenance of meristems; thus, the correlation between cytokinin and auxin is critical for forming the entire plant body (Su, Liu, \& Zhang, 2011). During those processes, xylem and phloem are the vascular tissues that connect the entire plant body; while phloem transfers and distributes photoassimilates synthesized in the shoot, xylem carries minerals and water from the roots and provides the plant with its structure and girth (Milhinhos \& Miguel, 2013).

The comparative quantities of phloem and xylem are regulated and formed by auxin concentrations. While xylem differentiation occurs at high auxin concentrations, phloem differentiation occurs at low auxin concentrations. Also, cytokinins induce early phases of vascular differentiation in the presence of auxins,: otherwise, cytokinins enhances tissue sensitivity to auxin stimulation (Aloni, 1995). Largely, effects of plant growth regulators (PGRs) on vascular tissues have been investigated in trees and rose and make a relatively new research interest in other plants (Little \& Pharis, 1995; Eriksson, Israelsson, Olsson, \& Moritz, 2000; Björklund, Antti, Uddestrand, Moritz, \& Sundberg, 2007; Guo et al., 2015; Johnsson et al., 2018; Monder, Kozakiewicz, \& Jankowskab, 2019). Previous studies have revealed that indole-3-acetic acid (IAA), as an auxin, has a significant role in cambial activity and wood formation of woody plants (Little \& Pharis, 1995; Savidge, 1996). A related research was established by Yuan et al. (2019) in Populus simonii $\times$ P. nigra. The auxin treated seedlings increased xylem-to-phloem ratios in comparison. Also, xylem thickness was found at the highest after auxin treatments and there was no significant difference in phloem thickness between the auxin concentrations compared to controls (Yuan et al., 2019). There is no research upon cytokinin and auxin effects on the plant development and vascular tissues under both in vitro tissue culture conditions and anatomical studies in legumes. This study aimed to investigate the effects of various concentrations of cytokinin and cytokinin-auxin on anatomical features of L. culinaris tissue development treated for different periods in days under in vitro conditions to determine whether the time period of treatment affected rooting behavior of the treated shoots.

\section{Material and Methods}

\subsection{Plant material and surface sterilization}

Seeds of lentil cultivar Çiftçi were provided from the General Directorate of Agricultural Research at Yenimahalle Ankara, Turkey. Undamaged healthy seeds were preferred and picked manually prior to surface sterilization. The lentil seeds were sterilized for 15 minutes in $100 \%$ commercial bleach including $5 \% \mathrm{NaOCl}$ and then rinsed 3 times with sterile distilled water for 3 minutes.

\subsection{Medium, culture conditions, and plant explant}

In tissue media; MS medium (Murashige \& Skoog, 1962) supplemented with $30 \mathrm{~g} / \mathrm{L}$ sucrose and $6.2 \mathrm{~g} / \mathrm{L}$ agar. BAP $(1 \mathrm{mg} / \mathrm{L})$ and NAA $(0.3,0.6,0.9,1.2 \mathrm{mg} / \mathrm{L})$ doses were added to the tissue media before autoclaving. IBA stock solution was sterilized with a millipore filter $0.45 \mu \mathrm{m}$ pore size. The $\mathrm{pH}$ of the culture medium was adjusted to 5.8 before adding agar and autoclave sterilization at $121 \mathrm{O}^{\circ} \mathrm{C}$ for 20 minutes. All cultures were incubated at $24{ }^{\circ} \mathrm{C}, 16$ hours light and 8 hours dark conditions. The seeds were placed horizontally at semi-submerged position in each culture treatment to achieve maximum germination rate.

The plants that germinated to a 2-3 cm length were cut off closer to cotyledon nodes and were transferred to the tissue medium including abovementioned plant growth regulator concentrations. The shoots were cultured periodically for different day (7, 14, 21, 28, 35 days) intervals with aforementioned BAP and NAA concentrations. After those treatments, the explants were cultured in rooting medium with $0.5 \mathrm{mg} / \mathrm{L} \mathrm{IBA}$ hormone for 30 days.

\subsection{Paraffin wax method}

Aforementioned BAP and NAA exposed lentil stems (0.5 $\mathrm{cm}$ length) were used for anatomical studies. The material was fixed in $70 \%$ ethyl alcohol for 7 days. Then, stem samples were placed in glass vials and dehydrated through alcohol series (50, 70, 85, and 100\%) and alcohol/xylene series $(2: 1,1: 1,1: 2)$ for 30 minutes in each. Afterward, they were rinsed in $100 \%$ xylene for 15 minutes each and glass vials were filled with $15 \mathrm{ml}$ of $100 \%$ xylene followed by adding 1 metal teaspoon of paraffin. Thereafter, the vials were gradually transferred to oven at $60{ }^{\circ} \mathrm{C}$. This was supposed to evaporate the xylene and promote the full wax infiltration of the tissues. After a period of $24 \mathrm{~h}$ with constant addition of wax, the tissues were embedded in paraffin wax when the vials were in the oven at $60^{\circ} \mathrm{C}$.

After 7 days, the stems were placed in moulds and filled with molten paraffin cooled in refrigerator at $-20^{\circ} \mathrm{C}$. The moulds were later removed and the "wax-cubed" containing the tissues were trimmed with bistoury and sectioned using a Leica RM2125RTS rotary microtome at 10 to $15 \mu \mathrm{m}$ thickness. The wax ribbon section was collected on already egg-albumen-smeared slides. The slides were placed on waterbath at $50{ }^{\circ} \mathrm{C}$ for 3 minutes. The sections were de-waxed in pure xylene and rehydrated in alcohol series in the order of $100,85,70$, and $50 \%$ for 5 minutes each. All sections were stained with Safranin and Fast Green and mounted with Entellan (Johansen, 1940). Photomicrographs were taken using a Leica DM500 light microscope.

\subsection{Measurements}

Plant height was measured with a digital caliper. Phloem and xylem thickness, stem radius were measured using Leica application suite version 3.4 .0 in all three replications. Although stem diameter was relatively preferred, we preferred to measure stem radius both vertical and horizontal in order to minimize measuring faults stemming from deformity in stem shape. Then average of four measurements were accepted as the stem radius in all replications.

\subsection{Statistical Analysis}

The experiment was established in completely randomized factorial experiment design in 3 replications with 5 explants in each treatment. Significance was determined by analysis of variance (ANOVA) and the differences between the means were compared by Tukey's multiple comparisons post hoc test using the JMP data analysis tool. 


\section{Results}

Plant height, number of shoots per plant, xylem and phloem region's thickness, xylem region/phloem region ratio, and stem radius were analyzed. There was no statistical significance among replications and also the explants responded homogeneously within and among replications. According to the analysis of variance results; significant differences $(p<0.01)$ were noted among plant growth regulator treatments and day treatment intervals and a significant interaction $(p<0.01)$ was noted among plant growth regulator doses $\times$ day treatment intervals (except for xylem/phloem regions percentage in plant growth regulator $\times$ day treatments).

\subsection{Plant Height}

Plant height was recorded and observed on all culture media with $100 \%$ viability and during the experiment no contamination was observed. Determination of the optimal culture media is a major concern in vitro plant regeneration and development. The maximum plant height was observed on $1 \mathrm{mg} / \mathrm{L} \mathrm{BAP}+0.6 \mathrm{mg} / \mathrm{L} \mathrm{NAA}$ treatment with 7 days of culture. This trend was followed by treatment of $1 \mathrm{mg} / \mathrm{L} \mathrm{BAP}+0.3 \mathrm{mg} / \mathrm{L} \mathrm{NAA}$ with 7 days of culture. It was obvious that the average maximum plant height was obtained after 7 days of culture (Table 1). High doses of BAP and NAA treatments and prolonged day treatments influenced plant height negatively producing shorter plantlets (Fig. 1c).

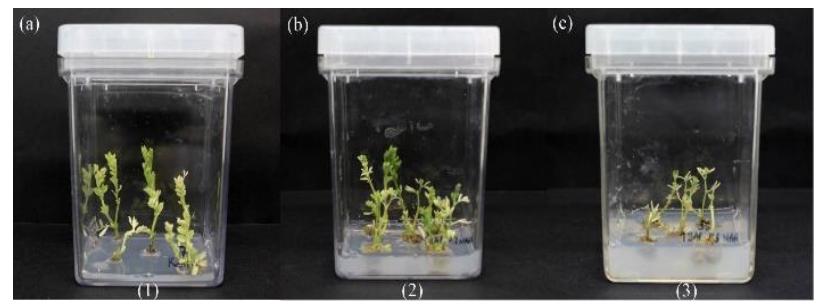

Figure 1. (a) 7 days culture, (b) 21 days of culture, (c) 35 days of culture (1) Control (absence of BAP and NAA), (2) $1 \mathrm{mg} / \mathrm{L} \mathrm{BAP} \mathrm{+}$ $0.3 \mathrm{mg} / \mathrm{L} \mathrm{NAA}$ (3) $1 \mathrm{mg} / \mathrm{L} \mathrm{BAP}+0.6 \mathrm{mg} / \mathrm{L} \mathrm{NAA}$

It was significant to note that plant height showed a declined growth after 21 days of culture using all plant growth regulator doses when average values were taken into consideration (Table 1). High doses of BAP and NAA caused unhealthy plant growth after 21 days of culture.

\subsection{Number of shoots per explant}

It is clear that BAP, as a cytokinin, activated shoot production by inducing new germinating buds. Average value was the highest on $1 \mathrm{mg} / \mathrm{L}$ BAP treatment singly when compared to other treatments all together (Table 2). 21 days of BAP treatment achieved the highest rate of shoot regeneration. It was noted that different periods of culture in days had statistically similar effects on number of shoots regenerated per explant. NAA inhibited shoot regeneration. All groups that were treated with NAA showed low rate of shoot regeneration per explant. Our findings are in agreement with Müller and Leysers (2011).

\subsection{Width of phloem region of the stem}

Width of phloem region of the stem was the highest in control group by average value. The differences between the control group and other applications were statistically significant. It was noted that the differences between periods in day applications were also statistically significant on width of phloem region of the stem. The highest phloem thickness obtained from 7 and 14 days of culture applications respectively (Table 3 ). Prolonged days of culture with plant growth regulator treatments caused degeneration of cells and shrinking in phloem region. In addition, treatment periods for 35 days lead to degeneration and narrowing in phloem tissues as well (Fig. 2e). This consequently affected plant growth and could be a reason for poor plant growth and development in prolonged days treatments especially using high doses of BAP and NAA (Fig. 1c). Moreover, BAP and NAA treatment did not affect width of pith and existence of fascicular and interfascicular cambium (Fig. 2).

The results of this study are not in agreement with Yuan et al. (2019). They depicted that there were no notable differences between the IAA treatment and control treatment in phloem thickness in Populus simonii $\times$ P. nigra. These differences in results may have occurred due to different plant species used in these two studies. The results of this study are in agreement with Monder, Kozakiewicz and Jankowskab (2019) in terms of phloem region width. They found that measurement of phloem width was higher in control treatment compared to their width in NAA-treated plantlets.
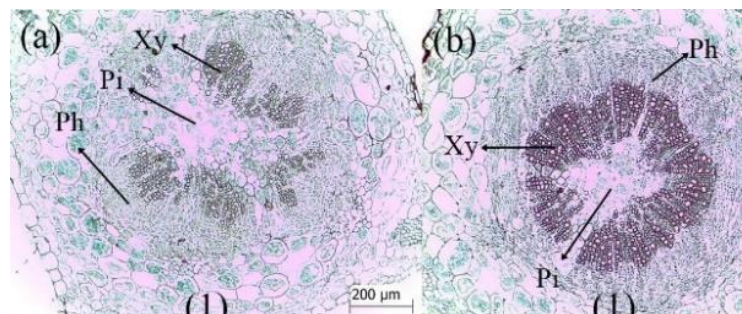

(1)
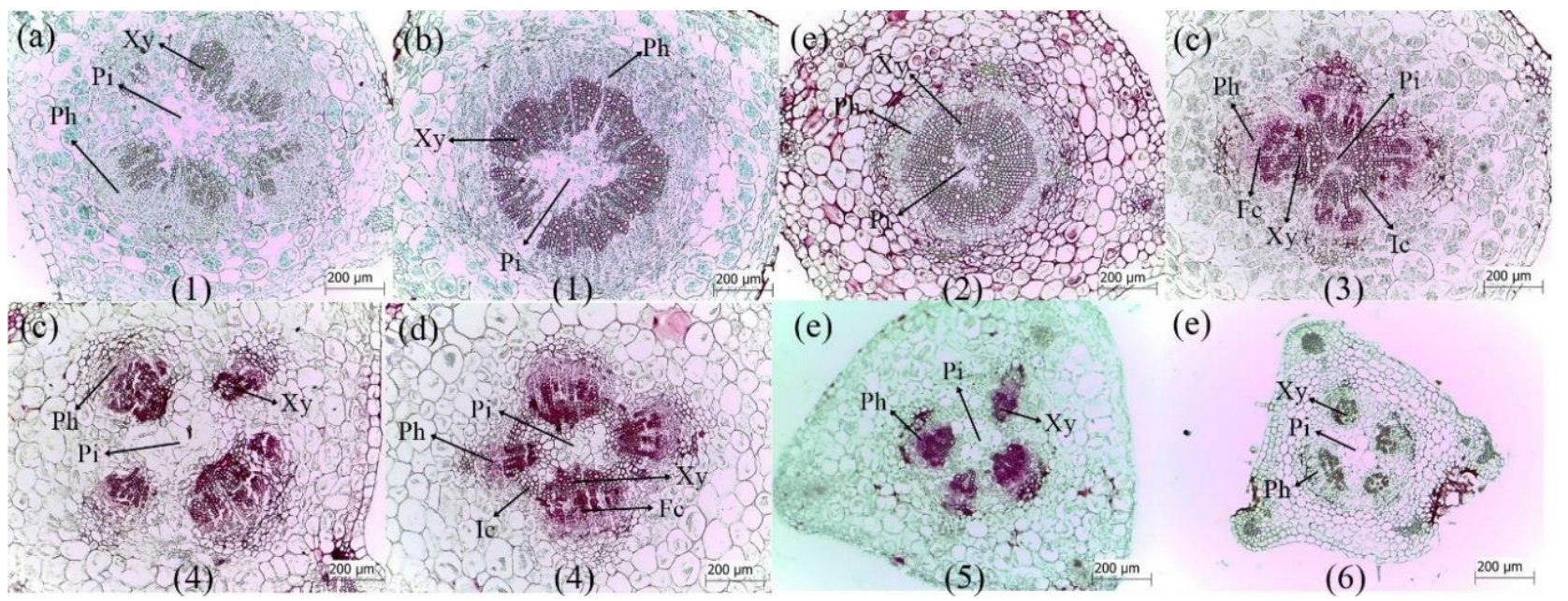

(e)

(3)

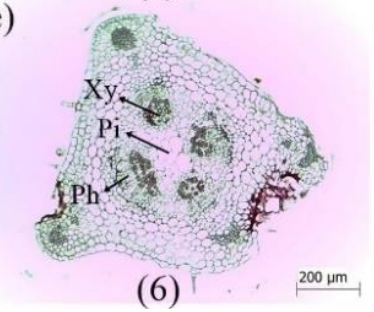

Figure 2. Cytokinin and auxin treated phloem and xylem tissues; (a) 7 days culture, (b) 14 days of culture, (c) 21 days of culture, (d) 28 days of culture, (e) 35 days culture, (1) Control (absence of BAP and NAA), (2) $1 \mathrm{mg} / \mathrm{L} \mathrm{BAP}$, (3) $1 \mathrm{mg} / \mathrm{L} \mathrm{BAP}+0.3 \mathrm{mg} / \mathrm{L} \mathrm{NAA}$, (4) 1 $\mathrm{mg} / \mathrm{L} \mathrm{BAP}+0.6 \mathrm{mg} / \mathrm{L} \mathrm{NAA}$, (5) $1 \mathrm{mg} / \mathrm{L} \mathrm{BAP}+0.9 \mathrm{mg} / \mathrm{L} \mathrm{NAA},(6) 1 \mathrm{mg} / \mathrm{L} \mathrm{BAP}+1.2 \mathrm{mg} / \mathrm{L}$ NAA 
Küplemez \& Yıldırım (2020) Comm. J. Biol. 4(1): 16-21.

Table 1. Effects of different cytokinin and auxin concentrations and day interval treatments on plant height (cm) of L. culinaris

\begin{tabular}{|c|c|c|c|c|c|c|c|}
\hline Days & $\begin{array}{c}\text { Control } \\
\text { (No treatment) }\end{array}$ & $1 \mathrm{mg} / \mathrm{L} \mathrm{BAP}$ & $\begin{array}{c}1 \mathrm{mg} / \mathrm{L} \text { BAP } \\
0.3 \mathrm{mg} / \mathrm{L} \text { NAA }\end{array}$ & $\begin{array}{c}\text { Treatments } \\
1 \mathrm{mg} / \mathrm{L} \text { BAP } \\
0.6 \mathrm{mg} / \mathrm{L} \text { NAA }\end{array}$ & $\begin{array}{c}1 \mathrm{mg} / \mathrm{L} \text { BAP } \\
0.9 \mathrm{mg} / \mathrm{L} \text { NAA }\end{array}$ & $\begin{array}{c}1 \mathrm{mg} / \mathrm{L} \text { BAP } \\
1.2 \mathrm{mg} / \mathrm{L} \text { NAA }\end{array}$ & Average \\
\hline 7 & $4.80 \mathrm{ad}^{*}$ & $5.04 \mathrm{ad}$ & $6 \mathrm{ab}$ & $7.78 \mathrm{a}$ & $5.74 \mathrm{ac}$ & $3.45 \mathrm{bd}$ & $5.46 \mathrm{a}^{\mathrm{w}}$ \\
\hline 14 & $5.56 \mathrm{ad}$ & $4.92 \mathrm{ad}$ & $4.50 \mathrm{ad}$ & $4.04 \mathrm{bd}$ & $3.47 \mathrm{bd}$ & $2.69 \mathrm{bd}$ & $4.19 \mathrm{~b}$ \\
\hline 21 & $5.93 \mathrm{ab}$ & $5.17 \mathrm{ad}$ & $4.10 \mathrm{bd}$ & $2.94 \mathrm{bd}$ & $2.01 \mathrm{~d}$ & $2.34 \mathrm{bd}$ & $3.74 \mathrm{~b}$ \\
\hline 28 & $5.20 \mathrm{ad}$ & $5.38 \mathrm{ad}$ & $3.78 \mathrm{bd}$ & $2.84 \mathrm{bd}$ & $3.26 \mathrm{bd}$ & $2.52 \mathrm{bd}$ & $3.83 \mathrm{~b}$ \\
\hline 35 & $5.16 \mathrm{ad}$ & $5.21 \mathrm{ad}$ & $2.66 \mathrm{bd}$ & $2.24 \mathrm{~cd}$ & $2.38 \mathrm{bd}$ & $2.33 \mathrm{bd}$ & $3.33 \mathrm{~b}$ \\
\hline Average value & $5.33 a^{y}$ & $5.14 \mathrm{ab}$ & $4.2 \mathrm{ac}$ & $3.96 \mathrm{bc}$ & $3.37 \mathrm{~cd}$ & $2.66 \mathrm{~d}$ & \\
\hline
\end{tabular}

For all tables:

*All values shown by the same letter in a single block are significantly different using Tukey's at 0.01 level of significance

w All values shown by the same letter in a single column are significantly different using Tukey's at 0.01 level of significance

${ }^{y}$ All values shown by the same letter in a single row are significantly different using Tukey's at 0.01 level of significance

Table 2. Effects of different cytokinin and auxin concentrations and day interval treatments on number of shoots per plant in L. culinaris

\begin{tabular}{|c|c|c|c|c|c|c|c|}
\hline \multirow[b]{2}{*}{ Days } & \multicolumn{7}{|c|}{ Number of shoots per explant } \\
\hline & $\begin{array}{c}\text { Control } \\
\text { (No treatment) }\end{array}$ & $1 \mathrm{mg} / \mathrm{L} \mathrm{BAP}$ & $\begin{array}{c}1 \mathrm{mg} / \mathrm{L} \text { BAP } \\
0.3 \mathrm{mg} / \mathrm{L} \text { NAA }\end{array}$ & $\begin{array}{c}1 \mathrm{mg} / \mathrm{L} \text { BAP } \\
0.6 \mathrm{mg} / \mathrm{L} \text { NAA }\end{array}$ & $\begin{array}{c}1 \mathrm{mg} / \mathrm{L} \text { BAP } \\
0.9 \mathrm{mg} / \mathrm{L} \text { NAA }\end{array}$ & $\begin{array}{c}1 \mathrm{mg} / \mathrm{L} \text { BAP } \\
1.2 \mathrm{mg} / \mathrm{L} \text { NAA }\end{array}$ & Average value \\
\hline 7 & $0.86 \mathrm{ad}^{*}$ & $0.86 \mathrm{ad}$ & $0.93 \mathrm{ad}$ & $1.06 \mathrm{ad}$ & $1.06 \mathrm{ad}$ & $0.80 \mathrm{ad}$ & $0.92^{w}$ \\
\hline 14 & $0.66 \mathrm{bd}$ & $1.46 \mathrm{ac}$ & $1.13 \mathrm{ad}$ & $0.40 \mathrm{bd}$ & $0.40 \mathrm{bd}$ & $0.33 \mathrm{bd}$ & 0.73 \\
\hline 21 & $0.60 \mathrm{bd}$ & $2.06 \mathrm{a}$ & $1 \mathrm{ad}$ & $0.46 \mathrm{bd}$ & $0.06 \mathrm{~d}$ & $0.20 \mathrm{~cd}$ & 0.73 \\
\hline 28 & $1.13 \mathrm{ad}$ & $1 \mathrm{ad}$ & $1.06 \mathrm{ad}$ & $0.20 \mathrm{~cd}$ & $0.60 \mathrm{bd}$ & $0.40 \mathrm{bd}$ & 0.73 \\
\hline 35 & $0.66 \mathrm{bd}$ & $1.53 \mathrm{ab}$ & $0.53 \mathrm{bd}$ & $0.20 \mathrm{~cd}$ & $0.33 \mathrm{bd}$ & $0.20 \mathrm{~cd}$ & 0.57 \\
\hline Average value & 0.78 bcy & $1.38 \mathrm{a}$ & $0.93 \mathrm{~b}$ & $0.46 \mathrm{c}$ & $0.49 \mathrm{c}$ & $0.38 \mathrm{c}$ & \\
\hline
\end{tabular}

Table 3. Phloem thickness measurements of L. culinaris $(\mu \mathrm{m})$ treated with different concentrations of cytokinin and auxin in variable day intervals

\begin{tabular}{|c|c|c|c|c|c|c|c|}
\hline Days & $\begin{array}{c}\text { Control } \\
\text { (No treatment) }\end{array}$ & $1 \mathrm{mg} / \mathrm{L} \mathrm{BAP}$ & $\begin{array}{c}1 \mathrm{mg} / \mathrm{L} \text { BAP } \\
0.3 \mathrm{mg} / \mathrm{L} \text { NAA }\end{array}$ & $\begin{array}{c}\text { Treatments } \\
\text { 1mg/L BAP } \\
0.6 \mathrm{mg} / \mathrm{L} \mathrm{NAA}\end{array}$ & $\begin{array}{c}1 \mathrm{mg} / \mathrm{L} \text { BAP } \\
0.9 \mathrm{mg} / \mathrm{L} \text { NAA }\end{array}$ & $\begin{array}{c}1 \mathrm{mg} / \mathrm{L} \text { BAP } \\
1.2 \mathrm{mg} / \mathrm{L} \text { NAA }\end{array}$ & Average value \\
\hline 7 & $100.67 \mathrm{ab}^{*}$ & 69.88 aj & $94.82 \mathrm{ac}$ & 84.91 af & 88.48 ae & $104 \mathrm{a}$ & $90.46 \mathrm{a}^{\mathrm{w}}$ \\
\hline 14 & $106.03 \mathrm{a}$ & $91.04 \mathrm{ad}$ & 69.97 aj & $63.64 \mathrm{bj}$ & 73.89 ai & 85.76 ae & $81.72 \mathrm{a}$ \\
\hline 21 & $102.17 \mathrm{ab}$ & $55.30 \mathrm{dj}$ & $67.41 \mathrm{aj}$ & $57.98 \mathrm{cj}$ & $46.36 \mathrm{fj}$ & $56.18 \mathrm{cj}$ & $64.23 \mathrm{~b}$ \\
\hline 28 & $61.60 \mathrm{cj}$ & $57.61 \mathrm{cj}$ & 50.82 ej & $54.79 \mathrm{dj}$ & $79.95 \mathrm{ag}$ & $57.65 \mathrm{cj}$ & $60.40 \mathrm{~b}$ \\
\hline 35 & $75.18 \mathrm{ah}$ & $42.55 \mathrm{gj}$ & $35.66 \mathrm{ij}$ & $46.79 \mathrm{fj}$ & $38.52 \mathrm{hj}$ & $33.44 j$ & $45.35 \mathrm{c}$ \\
\hline Average value & 89.13 ay & $63.27 \mathrm{~b}$ & $63.73 \mathrm{~b}$ & $61.62 \mathrm{~b}$ & $65.44 \mathrm{~b}$ & $67.41 \mathrm{~b}$ & \\
\hline
\end{tabular}

\subsection{Width of xylem region on the stems}

The results of this study showed that $1 \mathrm{mg} / \mathrm{L}$ BAP treatment induced the highest xylem region width on the stem and the same region width on control group plantlets was the lowest. A period of 7 days of culture treatments induced the highest xylem region thickness compared to any periodic day intervals by average value that showed a gradual reduction in xylem region with each increase period of treatment and dose dependent manner. A period of 35 days culture of $1 \mathrm{mg} / \mathrm{L} \mathrm{BAP}+1.2 \mathrm{mg} / \mathrm{L}$ NAA showed the least xylem region width (Table 4 ).

Xylem/phloem ratio was the highest using $1 \mathrm{mg} / \mathrm{L}$ BAP treatment with regards to average values including all culture periods in days. Whereas, the control group and $1 \mathrm{mg} / \mathrm{L} \mathrm{BAP}+1.2 \mathrm{mg} / \mathrm{L}$ NAA treatment showed the least xylem/phloem ratio (Table 5).

Results of the xylem/phloem ratios were in line with the xylem and phloem measurements along with both treatment periods in days and plant growth regulator treatments. Plant development and vascular tissues showed stressed growth due to increased BAP and NAA doses after prolonged culture periods in days. These results are in contradiction to a study carried out by Yuan et al. (2019) in which the researchers showed that IAA treatments induced the highest xylem region width. This study showed that NAA treatments caused the lowest xylem region width. There are relatively few studies on the effects of cytokinin-auxin on vascular tissues. Moreover, these findings on xylem region width showed similarity with a study carried out by Monder, Kozakiewicz and Jankowskab (2019). The researchers found that the control group treatments lead to higher increase in xylem region of rambler roses stem sample compared to the stem samples taken from NAA-treated group.

\subsection{Stem radius}

Stem radius measurement results showed parallel behavior in line with phloem and xylem regions width when culture periods' treatments in days are considered (Tables 3, 4, 6). 7 days of culture treatment period induced the largest stem radius. The stem radius showed decline with each increase in period in days from 14, 21, 28, and 35 days of culture. Extended days of culture treatments had negative effects on horizontal expansion of stems and induced shrinking on stem (Table 6; Fig. 2e). The largest average stem radius was observed on $1 \mathrm{mg} / \mathrm{L}$ BAP treatment, $1 \mathrm{mg} / \mathrm{L} \mathrm{BAP}+0.3 \mathrm{mg} / \mathrm{L} \mathrm{NAA}$ and $1 \mathrm{mg} / \mathrm{L} \mathrm{BAP}$ $+0.6 \mathrm{mg} / \mathrm{L}$ NAA treatment. Control group and $1 \mathrm{mg} / 1$ $\mathrm{BAP}+0.9 \mathrm{mg} / \mathrm{L} \mathrm{NAA}$ treatments induced the shortest average stem radius. 35 days culture of $1 \mathrm{mg} / \mathrm{L} \mathrm{BAP}+1.2$ mg/L NAA showed the least stem radius (Table 6). Xylem thickness measurements and stem radius interestingly had a parallel behavior (Tables 4,6). The result also showed positive increase in length of stems after BAP treatments. The result is not supported by Matsumo-Kitano et al. (2008) in which the researchers found that cytokinins decreased stem diameter in Arabidopsis thaliana.

\subsection{Rooting}

Plant growth regulator treatment periods had a clear influence on rooting with $0.5 \mathrm{mg} / \mathrm{L} \mathrm{IBA}$. Only control group shoots that were precultured for 21, 28, and 35 days rooted. No rooting was noted on shoots precultured for 7 
and 14 days on MS medium. Any, BAP or BAP + NAA pretreatment inhibited root induction. It was noted that BAP and NAA treated shoots inhibited rooting primarily due to the deformation of vascular bundles in the root zone. It is well known that the adventitious roots are induced from pericycle cells very close to vascular tissues cells with stimulation to divide after treatment with auxin under tissue culture conditions. Division which then go on to produce lateral root meristems (Grant \& Fuller, 1970; Scott \& Norris, 1970). A disturbance in vascular tissue formation affects the connection of pericycles to the vascular tissue and rooting (Esau, 1977). The results of this study are in agreement and confirmation to these studies and suggest careful optimization in plant growth regulator treatments to avoid difficulty in rooting of tissue cultured plants.

Table 4. Xylem thickness measurements of L. culinaris $(\mu \mathrm{m})$ that treated with different concentrations of cytokinin and auxin in variable day intervals

\begin{tabular}{|c|c|c|c|c|c|c|c|}
\hline Days & $\begin{array}{c}\text { Control } \\
\text { (No treatment) }\end{array}$ & $1 \mathrm{mg} / \mathrm{L}$ BAP & $\begin{array}{c}1 \mathrm{mg} / \mathrm{L} \text { BAP } \\
0.3 \mathrm{mg} / \mathrm{L} \text { NAA }\end{array}$ & $\begin{array}{c}\text { Treatments } \\
1 \mathrm{mg} / \mathrm{L} \text { BAP } \\
0.6 \mathrm{mg} / \mathrm{L} \text { NAA }\end{array}$ & $\begin{array}{c}1 \mathrm{mg} / \mathrm{L} \text { BAP } \\
0.9 \mathrm{mg} / \mathrm{L} \text { NAA }\end{array}$ & $\begin{array}{c}1 \mathrm{mg} / \mathrm{L} \text { BAP } \\
1.2 \mathrm{mg} / \mathrm{L} \text { NAA }\end{array}$ & Average value \\
\hline 7 & $146.09 \mathrm{cg}^{*}$ & 207.54 ae & $251.81 \mathrm{ab}$ & 225.75 ae & $244.23 \mathrm{ac}$ & $281.99 \mathrm{a}$ & $226.23 \mathrm{a}^{\mathrm{w}}$ \\
\hline 14 & $167.42 \mathrm{bg}$ & $235.79 \mathrm{ad}$ & $173.42 \mathrm{bg}$ & 204.17 af & $154.77 \mathrm{bg}$ & 179.16 af & $185.78 \mathrm{~b}$ \\
\hline 21 & $160.23 \mathrm{bg}$ & $175.19 \mathrm{bg}$ & 221.29 ae & 198.93 af & $163.25 \mathrm{bg}$ & $135.61 \mathrm{dg}$ & $175.75 \mathrm{~b}$ \\
\hline 28 & $150.67 \mathrm{bg}$ & 182.44 af & $153.19 \mathrm{bg}$ & $170.47 \mathrm{bg}$ & 201.44 af & $129.38 \mathrm{eg}$ & $164.59 \mathrm{bc}$ \\
\hline 35 & $168.38 \mathrm{bg}$ & 184.03 af & $125.14 \mathrm{eg}$ & $158.99 \mathrm{bg}$ & $102.52 \mathrm{fg}$ & $72.64 \mathrm{~g}$ & $135.28 \mathrm{c}$ \\
\hline Average value & 158.55 by & $196.99 \mathrm{a}$ & $184.97 \mathrm{ab}$ & $191.66 \mathrm{ab}$ & $173.24 \mathrm{ab}$ & $159.75 \mathrm{~b}$ & \\
\hline
\end{tabular}

Table 5. Xylem/Phloem region's thickness ratios of L. culinaris $(\mu \mathrm{m})$ that treated with different concentrations of cytokinin and auxin in variable day intervals

\begin{tabular}{|c|c|c|c|c|c|c|c|}
\hline Days & $\begin{array}{c}\text { Control } \\
\text { (No treatment) }\end{array}$ & $1 \mathrm{mg} / \mathrm{L} \mathrm{BAP}$ & $\begin{array}{c}1 \mathrm{mg} / \mathrm{L} \text { BAP } \\
0.3 \mathrm{mg} / \mathrm{L} \text { NAA }\end{array}$ & $\begin{array}{l}\text { Treatments } \\
1 \mathrm{mg} / \mathrm{L} \text { BAP } \\
0.6 \mathrm{mg} / \mathrm{L} \mathrm{NAA}\end{array}$ & $\begin{array}{c}1 \mathrm{mg} / \mathrm{L} \text { BAP } \\
0.9 \mathrm{mg} / \mathrm{L} \text { NAA }\end{array}$ & $\begin{array}{c}1 \mathrm{mg} / \mathrm{L} \mathrm{BAP} \\
1.2 \mathrm{mg} / \mathrm{L} \text { NAA }\end{array}$ & Average \\
\hline 7 & $1.48 \mathrm{~d}^{*}$ & $2.98 \mathrm{ad}$ & $2.69 \mathrm{bd}$ & $2.84 \mathrm{ad}$ & $2.78 \mathrm{ad}$ & $2.81 \mathrm{ad}$ & $2.59 \mathrm{bc}^{\mathrm{w}}$ \\
\hline 14 & $1.58 \mathrm{~cd}$ & $2.60 \mathrm{bd}$ & $2.53 \mathrm{bd}$ & $3.19 \mathrm{ab}$ & $2.08 \mathrm{bd}$ & $2.10 \mathrm{bd}$ & $2.34 \mathrm{c}$ \\
\hline 21 & $1.56 \mathrm{~cd}$ & $3.19 \mathrm{ab}$ & $3.28 \mathrm{ab}$ & $3.44 \mathrm{ab}$ & $3.51 \mathrm{ab}$ & $2.38 \mathrm{bd}$ & $2.89 \mathrm{ab}$ \\
\hline 28 & $2.45 \mathrm{bd}$ & $3.16 \mathrm{ac}$ & $3.02 \mathrm{ad}$ & $3.14 \mathrm{ac}$ & $2.52 \mathrm{bd}$ & $2.26 \mathrm{bd}$ & $2.75 \mathrm{ac}$ \\
\hline 35 & $2.38 \mathrm{bd}$ & $4.31 \mathrm{a}$ & $3.51 \mathrm{ab}$ & $3.44 \mathrm{ab}$ & $2.74 \mathrm{ad}$ & $2.21 \mathrm{bd}$ & $3.09 \mathrm{a}$ \\
\hline Average value & $1.89 \mathrm{C}^{\mathrm{y}}$ & $3.24 \mathrm{a}$ & $3.06 \mathrm{a}$ & $3.21 \mathrm{a}$ & $2.72 \mathrm{ab}$ & $2.35 \mathrm{bc}$ & \\
\hline
\end{tabular}

Table 6. Stem radius measurements of L. culinaris $(\mu \mathrm{m})$ that treated with different concentrations of cytokinin and auxin in variable day intervals

\begin{tabular}{|c|c|c|c|c|c|c|c|}
\hline Days & $\begin{array}{c}\text { Control } \\
\text { (No treatment) }\end{array}$ & $1 \mathrm{mg} / \mathrm{L} \mathrm{BAP}$ & $\begin{array}{c}1 \mathrm{mg} / \mathrm{L} \mathrm{BAP} \\
0.3 \mathrm{mg} / \mathrm{L} \text { NAA }\end{array}$ & $\begin{array}{c}\text { Treatments } \\
\text { 1mg/L BAP } \\
0.6 \mathrm{mg} / \mathrm{L} \mathrm{NAA}\end{array}$ & $\begin{array}{c}1 \mathrm{mg} / \mathrm{L} \text { BAP } \\
0.9 \mathrm{mg} / \mathrm{L} \text { NAA }\end{array}$ & $\begin{array}{c}1 \mathrm{mg} / \mathrm{L} \text { BAP } \\
1.2 \mathrm{mg} / \mathrm{L} \text { NAA }\end{array}$ & Average value \\
\hline 7 & $709.74 \mathrm{fh}^{*}$ & $678.48 \mathrm{fi}$ & $955.31 \mathrm{c}$ & $984.49 \mathrm{c}$ & $898.19 \mathrm{~cd}$ & $1265.02 \mathrm{a}$ & $915.20 \mathrm{a}^{\mathrm{w}}$ \\
\hline 14 & $802.48 \mathrm{df}$ & $1122.08 \mathrm{~b}$ & $782.92 \mathrm{df}$ & 552.92 il & $467.38 \mathrm{kl}$ & $781.61 \mathrm{df}$ & $751.56 \mathrm{~b}$ \\
\hline 21 & $696.80 \mathrm{fh}$ & $746.26 \mathrm{eg}$ & $810.90 \mathrm{df}$ & 754.21 ef & $579.90 \mathrm{hk}$ & $532.53 \mathrm{jl}$ & $686.76 \mathrm{c}$ \\
\hline 28 & $530.16 \mathrm{jl}$ & $685.44 \mathrm{fi}$ & $578.14 \mathrm{hk}$ & 877.02 ce & $1004.5 \mathrm{bc}$ & $616.70 \mathrm{gj}$ & $715.32 \mathrm{bc}$ \\
\hline 35 & $604.10 \mathrm{hj}$ & $697.21 \mathrm{fh}$ & 752.77 ef & $743.48 \mathrm{fg}$ & $523.09 \mathrm{jl}$ & 441.991 & $627.10 \mathrm{~d}$ \\
\hline Average value & $668.65 \mathrm{cy}^{\mathrm{y}}$ & $785.89 \mathrm{a}$ & $776.01 \mathrm{a}$ & $782.42 \mathrm{a}$ & $694.61 \mathrm{bc}$ & $727.57 \mathrm{~b}$ & \\
\hline
\end{tabular}

\section{Conclusion}

In line with the findings, it was clearly determined that when the BAP and NAA application period was extended, it had a negative effect on rooting due to the deformation of vascular bundles in the Lens culinaris tissues. The development of negative effects of BAP and NAA on the vascular tissues in turn had a negative effect on pericycle cells and rooting of the plant. It is the first study to determine the effects of auxin and cytokinin on vascular tissues and development of lentil plants. It is believed that this study will shed a strong light on the tissue culture and rooting studies to be carried out in future.

Acknowledgements: This study was derived from a M.Sc. thesis of the first author at Department of Agricultural Sciences at Institute of Natural and Applied Sciences, Usak University, Usak, Turkey. The authors would like to express their gratitude to Assoc. Prof. Dr. Ahmet Kahraman from Department of Biology, Faculty of Arts and Sciences, Plant Systematics and Phylogenetics Laboratory (PSPL), Usak University for his constructive comments on the manuscript and excellent technical assistance on anatomical study.

\section{References}

Aloni, R. (1995). The Induction of Vascular Tissues by Auxin and Cytokinin. Plant Hormones, 531-546.
Bhatty, R.S. (1988). Composition and quality of lentil (Lens culinaris Medik.): a review. Canadian Institute of Food Science and Technology Journal, 21, 144160. https://doi.org/10.1016/S0315-5463(88)70770-1

Björklund, S., Antti, H., Uddestrand, I., Moritz, T., \& Sundberg, B. (2007). Cross-talk between gibberellin and auxin in development of Populus wood: Gibberellin stimulates polar auxin transport and has a common transcriptome with auxin. The Plant Journal, 52, 499-511. https://doi:10.1111/j.1365-313X.2007. 03250.x

Chhabra, G., Chaudhary, D., Varma, M., Sainger, M., \& Jaiwal, P.K. (2008). TDZ-induced direct shoot organogenesis and somatic embryogenesis on cotyledonary node explants of lentil (Lens culinaris Medik.). Physiology and Molecular Biology of Plants, 14, 347-353. https://doi:10.1007/s12298-008-0033-z

Eriksson, M.E., Israelsson, M., Olsson, O., \& Moritz, T. (2000). Increased gibberellin biosynthesis in transgenic trees promotes growth, biomass production and xylem fiber length. Nature Biotechnology, 18, 7847-7888. https://doi: 10.1038/77355

Esau, K. (1977). Anatomy of seed plants. 2nd ed. New York, John Wiley and Sons. 550 pp.

Evans, D.A., Sharp, W.R., \& Flick, C.E. (1981). Growth and behavior of cell cultures: embryogenesis and organogenesis. In: T. A. Thorpe (Ed), Plant cell culture: methods and applications in agriculture. New York, USA, Academic Press, 45-113.

Grant, M., \& Fuller, K.W. (1970). Biochemical changes associated with the growth of root tips of Vicia faba in vitro, and the effect of 2,4dichlorophenoxyacetic acid. Journal of Experimental Botany, 22, 49-59.

Guo, H., Wang, Y., Liu, H., Hu, P., Jia, Y. Zhang, C., Wang, Y., Gu, Yang, C., \& Wang, C. (2015). Exogenous GA3 Application Enhances Xylem Development and Induces the Expression of Secondary Wall 
Biosynthesis Related Genes in Betula platyphylla. International Journal of Molecular Sciences, 16, 22960-22975. https:/ / doi: 10.3390/ijms160922960

Johansen, D.A. (1940). Plant Microtechnique. New York, USA, McGrawHill Book Company, 523 pp.

Johnsson, C., Jin, X., Xue, W., Dubreuil, C., Lezhneva, L., \& Fischer, U. (2018). The plant hormone auxin directs timing of xylem development by inhibition of secondary cell wall deposition through repression of secondary wall NAC-domain transcription factors. Physiologia Plantarum, 165(4), 673 689. https://doi:10.1111/ppl.12766

Khanam, R., Sarker, R.H., Hoque, M.I., \& Haque, M.M. (1995). In vitro root morphogenesis in lentil (Lens culinaris Medik.). Plant Tissue Culture, 5, 35-41.

Khawar, K.M., Sancak, C., Uranbey, C., \& Ozcan, S. (2004). Effect of Thidiazuron on shoot regeneration from different explants of lentil (Lens culinaris Medik.) via organogenesis. Turkish Journal of Botany, 28, 421-426.

Khawar, K.M., \& Ozcan, S. (2002). Effect of indole-3-butyric acid on in vitro root development in lentil (Lens culinaris Medik.). Turkish Journal of Botany, 26(2), 109-111.

Little, C.H.A., \& Pharis, R.P. (1995). Hormonal control of radial and longitudinal growth in the tree stem. In: Gartner BL (ed) Plant stems: physiology and functional morphology. Academic Press, San Diego, 281-319.

Matsumoto-Kitano, M., Kusumoto, T., Tarkowski, P., Kinoshita-Tsujimura, K., Václavíková, K., Miyawaki, K., \& Kakimoto, T. (2008). Cytokinins are central regulators of cambial activity. Proceedings of the National Academy of Sciences, 105(50), 20027-20031. https://doi: 10.1073/pnas.0805619105

Milhinhos, A., \& Miguel, C.M. (2013). Hormone interactions in xylem development: a matter of signals. Plant Cell Report, 32, 867-883. https://doi:10.1007/s00299-013-1420-7

Monder, M.J., Kozakiewicz, P., \& Jankowskab, A. (2019). Anatomical structure changes in stem cuttings of rambler roses induced with plant origin preparations. Scientia Horticulturae, 255, 242-254. https://doi:10.1016/j.scienta.2019.05.034

Müller, D., \& Leyser, O. (2011). Auxin, cytokinin and the control of shoot branching. Annals of Botany, 107, 1203-1212. https://doi.org/10.1093/aob/mcr069

Murashige, T., \& Skoog, F. (1962). A revised medium for rapid growth and bioassays with tobacco tissue cultures. Physiologia Plantarum, 15, 473497.

Ozdemir, F.A., Turker, M., \& Khawar, K.M. (2015). Effects of plant growth regulators on lentil (Lens culinaris Medik.) cultivars. Bangladesh Journal of Botany, 44(1), 79-84. https://doi: 10.3329/bjb.v44i1.22727

Polanco, M.C., Pelaez, M.I., \& Ruiz, M.L. (1988). Factor affecting callus and shoot formation from in vitro cultures of Lens culinaris Medik. Plant Cell Tissue Organ Culture, 15, 175-182.

Polanco, M.C., \& Ruiz, M.L. (1997). Effect of benzylaminopurine on in vitro and in vivo root development in lentil. Plant Cell Reports, 44(17), 22-26. https://doi:10.1007/s002990050345

Sarker, R.H., Mustafa, B.M., Biswas, A., Mahbub, S., Nahar, M., Hashem, R., \& Hoque, M.I. (2003). In vitro regeneration in lentil (Lens culinaris Medik.). Plant Tissue Culture, 13, 155-163.

Savidge, R.A. (1996). Xylogenesis, genetic and environmental regulation. International Association of Wood Anatomists Journal, 17(3), 269-310. https:/ / doi:10.1163/22941932-90001580

Saxena, P.K., \& King, J. (1987). Morphogenesis in lentil: plant regeneration from callus cultures of Lens culinaris Medik. via somatic embryogenesis. Plant Science, 52, 223-227.

Scott, P.C., \& Norris, L.A. (1970). Separation of auxin and ethylene in pea roots. Nature, 227, 1366-1367.

Sevimay, C.S., Khawar, K.M., \& Yuzbasioglu, E. (2005). Adventitious shoot regeneration from different explants of wild lentil (Lens culinaris subsp. orientalis). Biotechnology \& Biotechnological Equipment, 19(2), 46-49.

Solh, M., \& Erskine, W. (1984). Genetic Resources of Lentils, Genetic Resources and Their Exploitation-Chickpeas, Faba Beans and Lentils. In J.R. Witcombe, W. Erskine(Eds), Martinus Nijhoff/Dr. W. Junk Publishers, Advances in Agricultural Biotechnology, 6, 205-221. https://doi.org/10.1007/978-94-009-6131-9_17

Su, Y.H., Liu, Y.B., \& Zhang, X.S. (2011). Auxin-cytokinin interaction regulates meristem development. Molecular Plant, 4(4), 616-625. https://doi.org/10.1093/mp/ssr007

Yuan, H., Zhao, L., Guo, W., Yu, Y., Tao, L, Zhang, L., Song, X., Huang, W. Cheng, L., Chen, J., Guan, F., Wu, G., \& Li, H. (2019). Exogenous Application of Plant growth regulators Promotes Growth and Regulates Expression of Wood Formation-Related Genes in Populus simonii $\times$ P. 